\title{
Diversity of soil mites (Acari: Mesostigmata: Gamasina) in various deciduous forest ecosystems of Muntenia region (southern Romania)
}

\author{
MINODORA MANU \\ Institute of Biology, Department of Ecology, Taxonomy and Nature Protection, \\ Splaiul Independenţei 296, 060031 Bucharest, Romania \\ Corresponding author: Minodora Manu, mindora_stanescu@yahoo.com
}

(Received on 7 February 2011; Accepted on 15 January 2013)

\begin{abstract}
The main task of the research was to investigate the diversity of predatory soil mites (Gamasina) in 8 types of forest ecosystems: alder (Călugăreni, Clinceanca, Azuga Valley, Cumpătu), oak-hornbeam (Baloteşti, Băneasa), beech (Şotrile), and fir-beech (Lunca Mare) in Muntenia region. Taxonomical classification and statistical methods used in this study show similarities as well as differences between their predatory mite communities. In total, 467 mites of 57 gamasid species were identified, belonging to 28 genera and 12 families. Veigaia nemorensis, Prozercon fimbriatus, P. kochii, and P. traegardhi were most abundant. Geographical position, abiotic factors (soil type, slope angle, soil moisture content, $\mathrm{pH}$ ) and biotic ones (vegetation structure: herbs, shrubs or trees) were related to differences in gamasid species composition between the investigated forest ecosystems.
\end{abstract}

Keywords: Gamasina, diversity, microclimate, mite, structure, similarity

\section{INTRODUCTION}

Natural forests are complex and very stable ecosystems. These characteristics are due to the specific ecological niches of all species, both aboveground and belowground, in the soil food web (Moore et al., 2005). The soil ecosystem contains many less studied but often abundant groups of mesofauna, such as soil mites and other microarthropods (COLEMAN \& WHITMAN 2005). Gamasids, as one group of soil mites, are predators, influencing population growth of other organisms and controlling the abundance of springtails, soil-dwelling mites, larvae and eggs of insects as well as nematodes and enchytraeids. Therefore they have an indirect effect on the structure and function of ecosystems, affecting decomposition of organic matter, nutrient cycling, and formation of mycorrhiza, being an important factor in soil formation and stabilization processes (KoEHLER 1997, 1999; BEDANo \& RUF 2010). In soil they find 
the most favourable conditions for their development. The structure and dynamics of their populations are usually specific to each type of ecosystems, depending on vegetation structure, soil type, and microclimate.

The main task of this research was to determine if the type of ecosystem in correlation with some abiotic factors influences the structure of soil mite communities in Romanian deciduous forests.

\section{MATERIAL AND METHODS}

\section{Study sites}

The study was conducted in 2004-2007 in 8 forest ecosystems: in Azuga Valley (1); Cumpătu (2), Şotrile (3) and Lunca Mare (4) in Doftana Valley; Baloteşti (5) and Băneasa (6) near Bucharest; and Călugăreni (7) and Clinceanca (8) in Giurgiu district. All of them are natural forests, within Muntenia region of Romania.

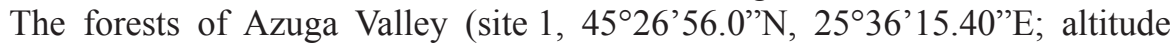
$1035 \mathrm{~m}$ ) and Cumpătu (site 2, 45 $21^{\prime} 59.6^{\prime \prime} \mathrm{N}, 2^{\circ} 33^{\prime} 02.50^{\prime \prime} \mathrm{E}$; altitude $828 \mathrm{~m}$ ) represent the plant association Telekio speciosae-Alnetum incanae Coldea (1986) 1990. They are located in the middle and lower parts of the Azuga Valley, on alluvial soil ( $\mathrm{pH}$ 7.1-8.5). The herb layer is composed of species characteristic of Carpathian beech forests, like Pulmonaria rubra, Symphytum cordatum, Campanula abietina, Carduus personata, Chaerophyllum hirsutum, Viola biflora, Geum rivale, Heracleum palmatum, and Delphinium elatum. The tree layer is dominated by Alnus incana (species common at high altitudes), comprising also Acer pseudoplatanus, Rosa caninna, Salix alba, and Sambucus nigra (FALCĂ et al. 2005a). Soil samples were collected there in 2004.

The forest ecosystem of Şotrile (site 3, 45 $13^{\prime} 39.67^{\prime} \mathrm{N}, 25^{\circ} 43^{\prime} 48.61^{\prime \prime} \mathrm{E}$; altitude $600 \mathrm{~m}$ ) is a beech forest with low productivity and moder humus of CalamagrostisLuzula type. The habitat is classified as R4106 South-East Carpathian beech and fir forest with Hieracium rotundatum. According to Natura 2000, the habitat type is 9110 Luzulo-Fagetum beech forest (DonițĂ et al. 2005). This ecosystem is situated on a slope of $30^{\circ}$. The soils are acid brown, brown iron-alluvial and podzolic, oligo- and oligo-mesobasic, with moderate to low soil moisture content, moderate to deep clayey-sandy, with small to moderate edaphic volume. Soil fertility is low. Soil samples were collected there in 2006.

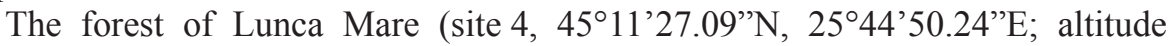
$490 \mathrm{~m}$ ) is a beech forest ecosystem of Epipactis-Cephalanthera type, with low productivity and mull-moder humus, on calcicolous and eubasic soils. The habitat is classified as R4111 South Carpathian beech forest of Fagus sylvatica and Abies alba with Cephalanthera damassonium (DoNiȚĂ et al. 2005). According to Natura 2000, the habitat is 9150 Medio-European limestone beech forest of the alliance Cephalanthero-Fagion. It is situated on a strongly fragmented relief with calcareous rocks on the surface, having a slope angle of $40^{\circ}$. The humid calcareous soil is not uniform in structure, varying from calcicolous, clayey to argillaceous or with mull humus. It has good airflow and drainage. Soil samples were collected there in 2005. 
Forest ecosystems of Baloteşti (site 5, 4442'45.8'N, 2608'49.9'"E; altitude

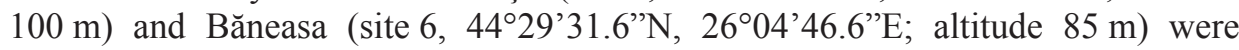
characterized by native trees, xero-mesophilous to mesophilous, meso-eutrophic to eutrophic, frequent from forest steppe to beech forests and from oak forest zones (Carpinus betulus L., Quercus cerris L., Quercus robur L., Robinia pseudoacacia L., Tilia cordata Miller, Ulmus minor Miller) and by trees cultivated for forestry and ornamental purposes, thermo-subthermophilous, frequent from forest steppe to oak forest zones, in forests and their edges with shrubs (Acer tataricum L., Ulmus minor Miller). At the altitude of 100-200 m a.s.l. of the forest steppe and forest areas, the mean temperature was high $\left(10.0-9.5^{\circ} \mathrm{C}\right)$ with mean precipitation quite low (700-800 mm, usually 450-750 mm), typical for these forests. The herb layer was dominated by xero-mesophilous to mesophilous perennials, rarely biennials and annuals, frequent from steppe to beech forest and boreal zones, shaded areas, forests, edges of forests, shrublands, ruderal places, and sometimes segetal weeds: Alliaria petiolata (Bieb.) Cavara et Grande, Bromus arvensis L., Chenopodium album L., Dactylis glomerata L., Daucus carota L., Lamium amplexicaule L., Plantago media L., Poa angustifolia L., Prunella vulgaris L., Rumex crispus L., Stellaria media (L.) Vill., Taraxacum officinale Weber ex. Wiggers, Trifolium repens L., Urtica dioica L. There were also meso-hygrophilous perennials, frequent from steppe to beech forest zones, and meadows (Agrostis stolonifera L.). The forests were represented by small patches of diverse plant associations. Distribution of the herb and shrub layers was discontinuous because of human impact, increased especially in Băneasa forests. The soil is sandy (Onete \& PAucĂ-ComĂnescu 2008; Manu 2008). Soil samples were collected there in 2007.

The forests of Călugăreni (site 7, 441' $25.19^{\prime \prime} \mathrm{N}, 25^{\circ} 57^{\prime} 56.45^{\prime \prime} \mathrm{E}$; altitude 54 m) and Clinceanca (site $8,44^{\circ} 08^{\prime} 39.53^{\prime \prime} \mathrm{N}, 26^{\circ} 07^{\prime} 35.45^{\prime \prime} \mathrm{E}$; altitude $85 \mathrm{~m}$ ) are classified as the association Stellario nemori-Alnetum glutinosae, specific to large valleys, where water flow is slower. As a consequence of alluvial accumulation, the land is elevated and becomes suitable for meso-hygrophilous meadows. The gley soils are permanently flooded by rivers, sometimes swampy, neutral to slightly basic ( $\mathrm{pH}$ 7.0-8.2). The tree layer is dominated by Alnus glutinosa (species common at low altitudes), comprising also Salix alba, Fraxinus pallisiae, F. excelsior, and Acer campestre. In the herb layer, Brachypodium sylvaticum, Aegopodium podagraria, Geum urbanum, Allium ursinum, and Rubus caesius are accompanied by meso-hygrophilous species of the classes Galio-Urticetea and Molinio-Arrhenatheretea (FALCĂ et al. 2005b). Soil samples were collected there in 2004.

In an effort to synthesize the presented material, the studied ecosystems were divided into 5 groups: alder forests of high altitudes (sites 1 and 2: Azuga Valley and Cumpătu); alder forests of low altitudes (sites 7 and 8: Călugăreni and Clinceanca); fir-beech forest (site 3: Şotrile); beech forest (site 4: Lunca Mare); and oak-hornbeam forests (sites 5 and 6: Băneasa and Baloteşti). 


\section{Sampling}

From each ecosystem, a total of 15 samples of soil were collected with MacFadyen corer ( $5 \mathrm{~cm}$ in diameter), to a depth of $10 \mathrm{~cm}$. The soil samples were taken 3 times in one year: 5 in spring (May), 5 in summer (July), and 5 in autumn (September) for each ecosystem. The mites were extracted with a modified Berlese-Tullgren funnel, in ethyl alcohol, and the mite samples were clarified in lactic acid. Mesostigmatid mites there identified to species level (Gilyarov \& Bregetova 1977; Hyatt 1980; KaRG 1993; MÁŠAn 2003; MášAn \& Fenda 2004; MÁŠAn 2007; GwiAZdowicz 2007; MÁšAn \& HALLIDAY 2010). In total, 120 soil samples were analysed, with 57 gamasid species and 467 individuals.

To measure the moisture content of the soil, 18 samples per year ( 6 per season) were collected from each ecosystem. The $\mathrm{pH}$ was measured with a C532 Jasco Consort-pH-meter. The moisture content of soil and $\mathrm{pH}$ for each area are represented by average annual values with standard deviation (Table 1).

\section{Mite community analysis}

After taxonomic identification, the number of individuals was the basis for calculation of density $\left(\mathrm{m}^{-2}\right)$, dominance index $D(\%)$, constancy index $C(\%)$, and Jaccard similarity index $J$.

Density $\left(\mathrm{m}^{-2}\right)$ was calculated using the formula ( $\sum$ no. of individuals/no. of samples) $* 1 \mathrm{~m}^{2} /$ surface area of the soil core (Botnariuc \& VădinEANU 1982). The surface area of the soil core was $19.63 \mathrm{~cm}^{2}$.

The results were analysed with the aid of BioDiversityPro 2.0 program, to calculate the Jaccard index $J$ for mite communities from the 8 studied forests.

$$
J=c /(a+b-c) \text {, }
$$

where: $a=$ number of species in ecosystem A; $b=$ number of species in ecosystem $\mathrm{B} ; c=$ number of species common to ecosystems $\mathrm{A}$ and $\mathrm{B}$.

The dominance index (\%) was calculated using the formula:

$$
D=100 \% * n / N \text {, }
$$

where: $n=$ number of individuals of one species in all samples; $N=$ total number of individuals of all species in all samples. Dominance classes for the identified gamasid mites were: eudominants with $D>10.0 \%$ (D5); dominants with $D$ of 5.1 $10.0 \%$ (D4); subdominants with $D$ of $2.1-5.0 \%$ (D3); recedents with $D$ of $1.1-2.0 \%$ (D2), and subrecedents with $D<1.1 \%$ (D1) (ENGELMANN 1978).

The constancy index (\%) was obtained using the formula:

$$
C=100 \% * p_{A} / P
$$

where: $p_{A}=$ number of samples with species $\mathrm{A} ; P=$ total number of samples. The mite species were classified in 4 constancy classes: euconstant species with $C$ of $75.1-100 \%$ (C4); constant species with $C$ of 50.1-75\% (C3); accessory species with $C$ of $25.1-50 \%$ (C2); and accidental species with $C$ of $1-25 \%$ (C1) (SELVIN \& VACCA 2004). 


\section{RESULTS}

Mean soil moisture content was the highest (43.75\%) at Baloteşti and the lowest $(14.73 \%)$ at Şotrile and Clinceanca $(15.27 \%)$. In other forests, soil moisture content was also low (means between $28.62 \%$ and $22.00 \%$ ). The most acidic soils were identified at Şotrile, Lunca Mare, Clinceanca, and Călugăreni, while basic ones at Cumpătu and Băneasa (Table 1). The recorded values of soil moisture content are not close to the optimum of $60 \%$, but some species are capable to adapt to the dryness, so species richness and diversity also recover rapidly (Metz 1971; Salmane 2000; MANu \& Honciuc 2010b).

Table 1. Annual averages of soil moisture content and $\mathrm{pH}$ in the studied forest ecosystems ( \pm standard deviation)

\begin{tabular}{|c|c|c|c|c|c|c|c|c|}
\hline \multirow{2}{*}{ Factor } & \multicolumn{8}{|c|}{ Forest sites } \\
\hline & 1 & 2 & 3 & 4 & 5 & 6 & 7 & 8 \\
\hline $\begin{array}{c}\text { Moisture } \\
(\%)\end{array}$ & $\begin{array}{l}28.30 \\
\pm 7.30\end{array}$ & $\begin{array}{l}24.93 \\
\pm 6.67\end{array}$ & $\begin{array}{l}14.73 \\
\pm 6.33\end{array}$ & $\begin{array}{l}28.17 \\
\pm 9.86\end{array}$ & $\begin{array}{l}43.75 \\
\pm 3.77\end{array}$ & $\begin{array}{l}28.62 \\
\pm 4.50\end{array}$ & $\begin{array}{l}22.00 \\
\pm 5.57\end{array}$ & $\begin{array}{l}15.27 \\
\pm 6.12\end{array}$ \\
\hline $\mathrm{pH}$ & $\begin{array}{r}7.10 \\
\pm 0.12\end{array}$ & $\begin{array}{r}8.50 \\
\pm 0.09\end{array}$ & $\begin{array}{r}4.89 \\
\pm 0.28\end{array}$ & $\begin{array}{r}5.52 \\
\pm 0.26\end{array}$ & $\begin{array}{r}7.00 \\
\pm 0.11\end{array}$ & $\begin{array}{r}8.20 \\
\pm 0.08\end{array}$ & $\begin{array}{r}5.87 \\
\pm 0.17\end{array}$ & $\begin{array}{r}5.07 \\
\pm 0.26\end{array}$ \\
\hline
\end{tabular}

In total, 57 species were identified, belonging to 28 genera and 12 families. Only 1 species occurred in all forests, while 12 were specific to oak-hornbeam forests (Băneasa, Baloteşti), 5 to beech-fir forest (Lunca Mare), 4 to beech forest (Şotrile), 12 to alder forests of low altitude, 3 to alder forests of high altitude and 20 to alder forests of both types (Călugăreni, Clinceanca, Cumpătu, Azuga Valley). The obtained numbers of gamasid species in the investigated areas are generally similar to those from other temperate forest ecosystems, where this parameter varies from 20 to 98 (Koenler 1997, 1999; Skorupski 2001, Gwiazdowicz \& Klemt 2004; Moraza 2006; Gulvik 2007; Skorupski et al. 2008, 2009; SAlmane \& Brumelis 2010; MAnu \& HonCIUC 2010a, b).

Considering spatial distribution, numbers of species and individuals were the highest at Călugăreni and Băneasa. Medium values were recorded at Cumpătu, Clinceanca, Lunca Mare, Azuga Valley, and Baloteşti. The lowest diversity was at Şotrile (possibly due to the steep slope of $40^{\circ}$, which caused instability of the organic layer). Analysing mite density in the investigated areas, the predatory mites had proper conditions for their development at Călugăreni, Băneasa, and Clinceanca, in comparison with the unfavourable conditions at Baloteşi, Cumpătu, Lunca Mare, Azuga Valley and Şotrile (Table 2). 
Table 2. Number of species, individuals, and density of gamasids in the studied forest ecosystems

\begin{tabular}{clccc}
\hline Site & Forest name & No. of species & $\begin{array}{c}\text { No. of } \\
\text { individuals }\end{array}$ & Density (ind./m²) \\
\hline 1 & Azuga & 14 & 22 & 747 \\
2 & Cumpătu & 17 & 31 & 1053 \\
3 & Şotrile & 12 & 33 & 1120 \\
4 & Lunca Mare & 15 & 62 & 2105 \\
5 & Baloteşti & 14 & 48 & 1630 \\
6 & Băneasa & 21 & 92 & 3124 \\
7 & Călugăreni & 23 & 93 & 3158 \\
8 & Clinceanca & 17 & 86 & 2920 \\
\hline
\end{tabular}

Species with the highest density per $\mathrm{m}^{2}$ were Leptogamasus parvulus, Lysigamasus lapponicus, Veigaia nemorensis, Pseudolaelaps doderoi, Asca aphidoides, Rhodacarellus kreuzi, Hypoaspis aculeifer, Pachylaelaps furcifer, Eviphis ostrinus, Zercon hungaricus, Prozercon kochi, P. plumatus, P. fimbriatus and P. traegardhi (Table 3).

Leptogamasus parvulus, Lysigamasus lapponicus and Veigaia nemorensis are very mobile predators, able to sustain large populations. Asca aphidoides and Rhodacarellus kreuzi are small-sized species capable of making horizontal migrations in search of suitable microhabitats in relation to the time of day or prevailing weather (Christian 1995; Koehler 1999; Lindberg \& Bengtsson 2006). Zercon hungaricus, Prozercon kochi, P. plumatus, P. fimbriatus and P. traegardhi are common eurytopic detritivores. They are most abundant and frequent in leaf litter and soil detritus of deciduous forests, especially with oak (MÁšAn \& FENDA 2004). The fact that these species are dominant in all investigated forests means that they apparently do prefer any forest type, being capable to adapt to various environmental conditions.

The high soil moisture content at Călugăreni and Băneasa created favourable habitats for gamasid communities, reflected by the number of identified species and their density per $\mathrm{m}^{2}$. Generally, in acid sandy soils the rate of decomposition is low, which could be related to the presence of fungi that generally dominate at low $\mathrm{pH}$. The presence of the fungi from acid soils is associated with abundant fungivores (e.g. nematodes, springtails, enchytraeids, and immature oribatids), which are food sources for gamasids (MARAUN et al. 2003). In spite of the high acidity of soils and of the small edaphic volume at Clinceanca, Lunca Mare, and Şotrile, the number of individuals of gamasids is lower there, due to the decreased moisture content.

The calcareous soil from Cumpătu is not a preferred abiotic condition for gamasid development. In this soil, bacteria are generally more abundant, and their presence is correlated with high soil pH (basic substrate) (KooIJMAN et al. 2009). Unfortunately, bacteria are not a favourable source of food for predatory mites (WALTER \& PROCTOR 1999; Maraun et al. 2003; Berg \& Bengtsson 2007). 
Two of identified gamasid species are eudominants (Veigaia nemorensis and Prozercon kochi), one is a dominant (Prozercon traegardhi), whereas the remaining 55 species are subdominants, recedents, and subrecedents. Considering the constancy index, $26.31 \%$ of species are euconstant; $19.29 \%$ are constant, and 55.4\% are accessory and accidental species (Table 3 ).

Table 3. Recorded soil mites (Acari: Mesostigmata: Gamasina) and their population parameters from all investigated forest ecosystems and seasons jointly. $\mathrm{SD}=$ standard deviation of number of individuals; $D=$ dominance; $C=$ constancy

\begin{tabular}{|c|c|c|c|c|c|c|}
\hline Species & $\begin{array}{c}\text { No. of } \\
\text { individuals }\end{array}$ & SD & $\begin{array}{l}\text { Density } \\
\text { (ind. } / \mathrm{m}^{2} \text { ) }\end{array}$ & $D(\%)$ & $\begin{array}{c}C \\
(\%)\end{array}$ & Forest type \\
\hline \multicolumn{7}{|l|}{ Epicriidae } \\
\hline $\begin{array}{l}\text { Epicrius mollis } \\
\text { (Kramer, 1876) }\end{array}$ & 2 & 0.89 & 68 & 0.43 & 20 & beech \\
\hline E. tauricus Bregetova, 1977 & 1 & 0.45 & 34 & 0.22 & 20 & alder (low alt.) \\
\hline \multicolumn{7}{|l|}{ Parasitidae } \\
\hline $\begin{array}{l}\text { Holoparasitus calcaratus } \\
\text { (C. L. Koch, 1839) }\end{array}$ & 1 & 0.45 & 34 & 0.22 & 20 & oak-hornbeam \\
\hline $\begin{array}{l}\text { H. cornutus } \\
\text { Juvara-Bals \& Witaliński, } \\
2000\end{array}$ & 4 & 0.84 & 136 & 0.87 & 60 & oak-hornbeam \\
\hline $\begin{array}{l}\text { Leptogamasus parvulus } \\
\text { (Berlese, 1903) }\end{array}$ & 12 & 2.51 & 408 & 2.60 & 80 & $\begin{array}{l}\text { alder (low and } \\
\text { high alt.), beech }\end{array}$ \\
\hline $\begin{array}{l}\text { L. variabilis } \\
\text { Juvara-Bals, } 1981\end{array}$ & 1 & 0.45 & 34 & 0.22 & 20 & beech \\
\hline Leptogamasus sp. & 3 & 0.89 & 102 & 0.65 & 40 & oak-hornbeam \\
\hline $\begin{array}{l}\text { Paragamasus similis } \\
\text { (Willmann, 1953) }\end{array}$ & 6 & 0.45 & 204 & 1.30 & 100 & alder (low alt.) \\
\hline $\begin{array}{l}\text { Pergamasus quisquiliarum } \\
\text { (R \& C. Canestrini, 1882) }\end{array}$ & 2 & 0.55 & 68 & 0.43 & 40 & oak-hornbeam \\
\hline P. laetus Juvara- Bals, 1970 & 10 & 1.22 & 340 & 2.16 & 100 & $\begin{array}{l}\text { alder (low alt.), } \\
\text { oak-hornbeam }\end{array}$ \\
\hline Pergamasus sp. & 7 & 1.14 & 238 & 1.52 & 80 & $\begin{array}{l}\text { alder (low and } \\
\text { high alt.), beech, } \\
\text { oak-hornbeam }\end{array}$ \\
\hline $\begin{array}{l}\text { Lysigamasus neoruncatellus } \\
\text { Schweizer, } 1961\end{array}$ & 1 & 0.45 & 34 & 0.22 & 20 & alder (low alt.) \\
\hline L. truncus Schweizer, 1961 & 3 & 0.89 & 102 & 0.65 & 40 & $\begin{array}{l}\text { beech, oak- } \\
\text { hornbeam }\end{array}$ \\
\hline $\begin{array}{l}\text { L. lapponicus } \\
\text { Tragardh, } 1910\end{array}$ & 7 & 1.52 & 238 & 1.52 & 60 & beech, fir-beech \\
\hline Lysigamasus sp. & 1 & 0.45 & 34 & 0.22 & 20 & oak-hornbeam \\
\hline L. conus Karg, 1971 & 1 & 0.45 & 34 & 0.22 & 20 & fir-beech \\
\hline $\begin{array}{l}\text { Parasitus beta } \\
\text { Oudemans \& Voigts, } 1904\end{array}$ & 2 & 0.55 & 68 & 0.43 & 40 & $\begin{array}{l}\text { alder (low and } \\
\text { high alt.) }\end{array}$ \\
\hline $\begin{array}{l}\text { P. furcatus } \\
\text { (R \& C. Canestrini, 1882) }\end{array}$ & 1 & 0.45 & 34 & 0.22 & 20 & alder (low alt.) \\
\hline $\begin{array}{l}\text { Vulgarogamasus kraepelini } \\
\text { (Berlese, 1905) }\end{array}$ & 1 & 0.45 & 34 & 0.22 & 20 & alder (low alt.) \\
\hline
\end{tabular}




\section{Veigaiidae}

Veigaia nemorensis

(C. L. Koch, 1839)

67

4.56

2278

14.50

100

alder (low and

high alt.), beech,

fir-beech,

oak-hornbeam

V. cervus (Kramer, 1876)

0.45

34

0.22

20

alder (low alt.)

V. exigua (Berlese, 1917)

$\begin{array}{llll}1.14 & 272 & 1.73 & 80\end{array}$

alder (low alt.),

beech, fir-beech, oak-hornbeam

\section{Ascidae}

Cheroseius sp.

Arctoseius eremitus

0.45

34

$0.22 \quad 20 \quad$ fir-beech

(Berlese, 1918)

0.45

34

0.22

20

alder (low alt.)

A. cetratus (Sellnick, 1940)

Leioseius magnanalis

(Evans, 1958)

Asca aphidoides

(Linne, 1758)

\section{A. bicornis}

1.41

$1.08 \quad 40$

alder (low alt.), fir-beech

(Caneastrini \& Fanzago, 1887)

Protogamasellus singularis

(Karg, 1962)

\section{Phytoseiidae}

Amblyseius sp.

Digamasellidae

Dendrolaelaps sp.

1

$$
0.45
$$

34

0.22

20

beech

4

0.84

136

0.87

60

alder (low and high alt.)

\section{Rhodacaridae}

Rhodacarellus kreuzi

Karg, 1965

16

4.09

544

3.46

80

alder (low and high alt.)

R. silesiacus

5

1.22

170

1.08

60

alder (low and high alt.), oakhornbeam

\section{Macrochelidae}

Neopodocinum mrciaki Sellnick, 1958

Macrocheles decoloratus

(C. L. Koch, 1839)

M. montanus

Willmann, 1951

Geholaspis longispinosus

(Kramer, 1876)

3

0.55

102

0.65

60

alder (high alt.)

4

1.30

136

0.87

40 alder (high alt.)

4

1.30

136

0.87

40

alder (low and

high alt.), fir-

beech

4

0.84

136

0.87

60

alder (low and high alt.)

\section{Pachylaelapidae}

Pachylaelaps furcifer Oudemans, 1903 


\begin{tabular}{|c|c|c|c|c|c|c|}
\hline $\begin{array}{l}\text { P. pectinifer } \\
\text { (G \& C. Canestrini, 1882) }\end{array}$ & 2 & 0.55 & 68 & 0.43 & 40 & oak-hornbeam \\
\hline $\begin{array}{l}\text { Olopachys vysotskajae } \\
\text { Koroleva, } 1976\end{array}$ & 2 & 0.55 & 68 & 0.43 & 40 & $\begin{array}{l}\text { alder (low and } \\
\text { high alt.) }\end{array}$ \\
\hline O. suecicus Sellnick, 1950 & 7 & 0.55 & 238 & 1.52 & 100 & $\begin{array}{l}\text { alder (low and } \\
\text { high alt.), beech, } \\
\text { oak-hornbeam }\end{array}$ \\
\hline $\begin{array}{l}\text { Pachyseius humeralis } \\
\text { Berlese, } 1910\end{array}$ & 3 & 0.55 & 102 & 0.65 & 60 & $\begin{array}{l}\text { fir-beech, oak- } \\
\text { hornbeam }\end{array}$ \\
\hline \multicolumn{7}{|l|}{ Laelapidae } \\
\hline $\begin{array}{l}\text { Pseudolaelaps doderoi } \\
\text { (Berlese, 1910) }\end{array}$ & 16 & 3.03 & 544 & 3.46 & 80 & $\begin{array}{l}\text { beech, oak- } \\
\text { hornbeam }\end{array}$ \\
\hline $\begin{array}{l}\text { Hypoaspis aculeifer } \\
\text { (Caneastrini, 1883) }\end{array}$ & 21 & 2.59 & 714 & 4.55 & 100 & $\begin{array}{l}\text { alder (low and } \\
\text { high alt.), beech, } \\
\text { fir-beech }\end{array}$ \\
\hline H. oblonga (Halbert, 1915) & 2 & 0.55 & 68 & 0.43 & 40 & $\begin{array}{l}\text { alder (low and } \\
\text { high alt.) }\end{array}$ \\
\hline H. miles Berlese, 1892 & 4 & 1.10 & 136 & 0.87 & 40 & oak-hornbeam \\
\hline \multicolumn{7}{|l|}{ Eviphididae } \\
\hline $\begin{array}{l}\text { Eviphis ostrinus } \\
\text { (C. L. Koch, 1836) }\end{array}$ & 5 & 1.22 & 170 & 1.08 & 60 & $\begin{array}{l}\text { alder (low and } \\
\text { high alt.) }\end{array}$ \\
\hline \multicolumn{7}{|l|}{ Zerconidae } \\
\hline $\begin{array}{l}\text { Zercon pinicola } \\
\text { Halaskova, } 1970\end{array}$ & 1 & 0.45 & 34 & 0.22 & 20 & alder (low alt.) \\
\hline $\begin{array}{l}\text { Z. triangularis } \\
\text { C. L. Koch, } 1836\end{array}$ & 7 & 1.67 & 238 & 1.52 & 60 & $\begin{array}{l}\text { alder (low and } \\
\text { high alt.) }\end{array}$ \\
\hline $\begin{array}{l}\text { Z. hungaricus } \\
\text { Sellnick, } 1958\end{array}$ & 11 & 1.48 & 374 & 2.38 & 80 & oak-hornbeam \\
\hline $\begin{array}{l}\text { Z. fageticola } \\
\text { Halaskova, } 1969\end{array}$ & 2 & 0.55 & 68 & 0.43 & 40 & $\begin{array}{l}\text { fir-beech, oak- } \\
\text { hornbeam }\end{array}$ \\
\hline $\begin{array}{l}\text { Prozercon plumatus } \\
\text { (Aoki, 1966) }\end{array}$ & 15 & 4.64 & 510 & 3.25 & 60 & $\begin{array}{l}\text { alder (low and } \\
\text { high alt.) }\end{array}$ \\
\hline P. kochi Selnick, 1943 & 40 & 7.65 & 1360 & 8.66 & 100 & $\begin{array}{l}\text { alder (low and } \\
\text { high alt.) }\end{array}$ \\
\hline $\begin{array}{l}\text { P. fimbriatus } \\
\text { (C. L. Koch, 1839) }\end{array}$ & 74 & 2.39 & 2516 & 16.02 & 100 & $\begin{array}{l}\text { alder (low alt.), } \\
\text { beech, fir-beech, } \\
\text { oak-hornbeam }\end{array}$ \\
\hline $\begin{array}{l}\text { P. traegardhi } \\
\text { (Halbert, 1923) }\end{array}$ & 31 & 5.17 & 1054 & 6.71 & 100 & $\begin{array}{l}\text { alder (low and } \\
\text { high alt.), beech, } \\
\text { fir-beech, oak- } \\
\text { hornbeam }\end{array}$ \\
\hline P. sellnicki Halaskova, 1963 & 2 & 0.55 & 68 & 0.43 & 40 & oak-hornbeam \\
\hline Prozercon sp. & 2 & 0.89 & 68 & 0.43 & 20 & beech \\
\hline Total & 467 & & 15878 & 100 & & \\
\hline
\end{tabular}


The high numbers of subdominant, recedent, subrecedent, accessory, and accidental species (taking into account the dominance and constancy indices) in beech, fir-beech, low-altitude alder, and oak-hornbeam forests indicate an unfavourable influence of environmental conditions (sandy soils with little organic matter, sometimes basic, dry) on stability of the studied populations. Their trophic spectrum determines high mobility, so it is possible that the identified species migrate to the study areas from adjacent ecosystems. Some authors show that predatory mites are influenced by the soil horizon and the period of collecting and not by altitude, without any significant interaction (SADAKA \& PONGE 2003). Each of the investigated ecosystems had a different species composition.

The dendrogram (Fig. 1) shows some similarities between species diversity of gamasids, explicable through the similarities in environmental conditions. For example, higher values of Jaccard index for Cumpătu vs. Călugăreni, as well as Baloteşti vs. Băneasa, were probably due to the same substrate (alluvial soil) and to the same primary producers (alder forests) and at Şotrile vs. Clinceanca due to the close values of soil moisture content and acidity. Low values of the Jaccard index were obtained for Azuga Valley compared to Lunca Mare, Şotrile, Băneasa, and Baloteşti (Table 4). This was probably due to differences in primary producers, altitude, soil type, and acidity for Lunca Mare vs. Azuga Valley; primary producers, moisture content, altitude, acidity, and soil type for Şotrile vs. Azuga Valley; primary producers and altitude for Băneasa vs. Azuga Valley; and soil moisture content for Baloteşti vs. Azuga (Fig. 1).

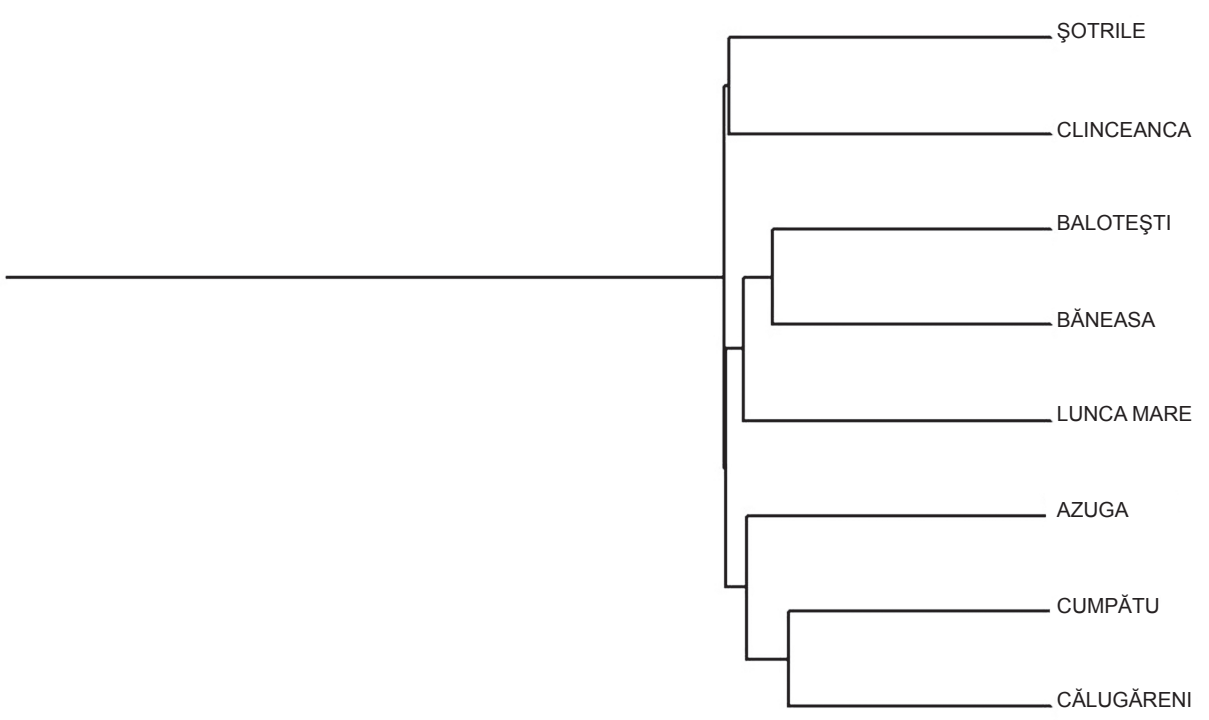

0 JACARD SIMILARITY

0,5

Fig. 1. Dendrogram based on the Jaccard similarity index of species composition between studied forest ecosystems 
Table 4. Jaccard index of similarity of gamasid species composition between the studied forest ecosystems. Values $>0.60$ are marked in bold

\begin{tabular}{lccccccc}
\hline & Clinceanca & Azuga & Cumpătu & Lunca Mare & Şotrile & Băneasa & Baloteşti \\
\cline { 2 - 8 } Călugăreni & $\mathbf{0 . 6 2}$ & 0.59 & $\mathbf{0 . 7 5}$ & 0.56 & 0.60 & 0.54 & 0.57 \\
Clinceanca & & 0.47 & $\mathbf{0 . 6 7}$ & $\mathbf{0 . 6 9}$ & $\mathbf{0 . 6 9}$ & $\mathbf{0 . 6 5}$ & 0.57 \\
Azuga & & & $\mathbf{0 . 7 1}$ & 0.33 & 0.33 & 0.37 & 0.38 \\
Cumpătu & & & & 0.49 & 0.52 & $\mathbf{0 . 6 9}$ & $\mathbf{0 . 6 9}$ \\
Lunca Mare & & & & $\mathbf{0 . 6 2}$ & $\mathbf{0 . 7 1}$ & 0.57 \\
Şotrile & & & & & 0.43 & 0.55 \\
Băneasa & & & & & & $\mathbf{0 . 7 3}$ \\
\hline
\end{tabular}

\section{CONCLUSIONS}

This study highlights the structural differences in gamasid communities. Considering species diversity and the dominance structure of gamasid mite communities, the alder forests of Călugăreni and oak-hornbeam forest of Băneasa had proper environmental conditions for mite development. The lowest gamasid abundance and species richness were recorded in the fir-beech forest of Şotrile. The small number of identified gamasid species, which usually had a low number of individuals, showed that most of the studied forests were unstable ecosystems.

Geographical position, abiotic factors (microclimate, soil type) and biotic ones (vegetation structure: herbaceous plants, shrubs, trees) determine the variation in species composition in each of the investigated forest ecosystems. High soil moisture content in correlation with vegetation structure caused a high species diversity in Băneasa and Călugăreni forests. By contrast, steep slopes $\left(30-40^{\circ}\right)$ of Lunca Mare and Şotrile as well as the slightly basic soil pH of Azuga and Baloteşti forests could determine the decreased species diversity of gamasids.

The structure of gamasid communities depended also on the geographical position and abiotic factors, which characterized the studied forest ecosystems. Development of Gamasina communities is influenced by microclimate, depending on vegetation structure (herbs, shrubs or trees), and on the litter and humus layers (the trophic reservoirs).

The dominant identified gamasid species differed in population structure, due to the various types of habitat (including vegetation layers), which offer several kinds of trophic sources. In this way, each studied forest ecosystems was described by the dominant gamasid species, with specific ecological preferences. These species can be considered as bioindicators for each type of studied forest ecosystems. 
Acknowledgements: This study was funded by project no. RO1567-IBB01/2013 "Researches concerning the relation between biodiversity and functions in some ecosystems from the Romanian Carpathians" from the Institute of Biology, Romanian Academy, Bucharest. Thanks are due to anonymous referees for their useful suggestions, constructive comments and advice.

\section{REFERENCES}

Bedano J., Ruf A. 2010. Sensitivity of different taxonomic levels of soil Gamasina to land use and anthropogenic disturbances. Agric. For. Entomol. 12: 203-212.

Berg P. M., Bengtsson J. 2007. Temporal and spatial variability in soil food web structure. Oikos 116: $1789-1804$.

Botnariuc N., VĂdinEAnu A. 1982. Ecologie [Ecology]. Editura Didactică şi Pedagogică, Bucureşti (in Romanian).

Christian A. 1995. Succesion of Gamasina in coal mine areas in Eastern Germany. Acta Zool. Fenn. 196: 380-381.

Coleman D. C., Whitman W. B. 2005. Linking species richness, biodiversity and ecosystem function in soil systems. Pedobiologia 49: 479-497.

Doniță C., Popescu A., Paucă Comănescu M., Mihăilescu S., Biriș I. 2005. Habitatele din România [Habitats from Romania]. Editura Tehnică şi Silvică, 269-271 (in Romanian).

Engelmann H. D. 1978. Zur Dominanzklassifizierung von Bodenarthropoden [Dominance classification of the epigeal arthropods]. Pedobiologia 18: 378-380.

Falcă M., Vasiliu-Oromulu L., Sanda V., Paucă-Comănescu M., Honciuc V., Maican S., Purice D., Tatole A., Stănescu M., Onete M., BițĀ-Nicolae C., Fiera C., Şincu E. D. 2005 a. The Biodiversity of the Alder Forest from the Montainous Valleys of the Girbova Massif. Proceedings of the Institute of Biology, Romanian Academy 7: 15-33.

Falcă M., Vasiliu-Oromulu L., Sanda V., Paucă-Comănescu M., Honciuc V., Maican S., Purice D., Tatole A., Stănescu M., Onete M., Biță-Nicolae C., Fiera C., Şincu E. D. 2005b. The Study of Preliminary and Secondary Producers from Some Alder Depression Forests of the Plain Zone. Proceedings of the Institute of Biology, Romanian Academy 7: 33-49.

Gilyarov M. S., Bregetova N. G. 1977. Opredeliteli obitayushchikh v pochve kleshchei Mesostigmata [A Key to Soil-Dwelling Mites (Mesostigmata)]. Akademia Nauk USSR, Zoologicheskii Institut Evolyucionoi Morfologii i Ekologii zhivotnikh im A.H. Savertova, Izd. Nauka, Leningrad.

Gwiazdowicz D., Klemt I. 2004. Mesostigmatic mites (Acari, Gamasida) in selected microhabitats of the Biebrza National Park (NE Poland). Biological Lett. 41: 11-19.

Gwiazdowicz D. 2007. Ascid mites (Acari, Gamasina) from selected forest ecosystems and microhabitats in Poland. University Augusta Cieszkowskiego, Poznań.

GulviK M. E. 2007. Mites (Acari) as indicators of soil biodiversity and land use monitoring: a review. Pol. J. Ecol. 55: 415-450.

Hyatт K. H. 1980. Mites of the subfamily Parasitinae (Mesostigmata: Parasitidae) in the British Isles. Bull. Br. Mus., Zoology series 38: 237-378.

KARG W. 1993. Acari (Acarina), Milben Parasitiformes (Anactinochaeta) Cohors Gamasina Leach - Raubmilben [Acari (Acarina) supraorder Parasitiformes (Anactinochaeta) Cohors Gamasina Leach - predatory mites]. Spektrum Akademischer Verlag (in German).

Koenler H. H. 1997. Mesostigmata (Gamasina, Uropodina) efficient predators in agroecosystems. Agricult. Ecosys. Environ. 62: 105-117.

Koenler H. H. 1999. Predatory mite's (Gamasina, Mesostigmata). Agricult. Ecosys. Environ. 74: 395-410. 
Lindberg N., Bengtsson J. 2006. Recovery of forest soil fauna diversity and composition after repeated summer droughts. Oikos 114: 494-506.

Kooijman A. M., MouriK J. M., Schilder M. L. M. 2009. The relationship between N mineralization or microbial biomass $\mathrm{N}$ with micromorphological properties in beech forest soils with different texture and $\mathrm{pH}$. Biol. Fertil. Soils 45: 449-459.

Manu M. 2008. Structure and dynamics of the predatory mites (Acari: Mesostigmata-Gamasina) from Bucharest. In: Species Monitoring in the central parks of Bucharest (CRĂCIUN I., Ed.), pp. 68-78, Editura Ars Docendi, Bucharest University.

Manu M., Honciuc V. 2010a. Ecological research on the soil mite's populations (Acari: Mesostigmata-Gamasina, Oribatida) from forest ecosystems near Bucharest city. Rom. J. Biol. - Zool. 55: $19-30$.

Manu M., Honciuc V. 2010b. Cercetări ecologice asupra populaţiilor de gamaside (Acari: Mesostigmata) din solurile unor ecosisteme forestiere din Masivul Bucegi-România. [Ecological researches on gamasid populations (Acari: Mesostigmata) from soils of some forest ecosystems from Bucegi Massif- Romania]. Structure and dynamics. Ars Docendi, University Bucharest (in Romanian).

Maraun M., Martens H., Migge S., Theenhaus A., Scheu S. 2003. Adding to 'the enigma of soil animal diversity': fungal feeders and saprophagous soil invertebrates prefer similar food substrates. Eur. J. Soil Biol. 39: 85-95.

MášAn P. 2003. Macrochelid mite's of Slovakia (Acari, Mesostigmata, Macrochelidae). Institute of Zoology, Bratislava, Slovak Academy of Science.

MÁŠAn P., FENDA P. 2004. Zerconid mite's of Slovakia (Acari, Mesostigmata, Zerconidae). Institute of Zoology, Bratislava, Slovak Academy of Science.

MÁšAn P. 2007. A review of the family Pachylaelapidae in Slovakia with systematics and ecology of European species (Acari: Mesostigmata: Eviphidoidea). Institute of Zoology, Slovak Academy of Science (Bratislava).

Mášan P., Halliday B. 2010. Review of the European genera of Eviphididae (Acari: Mesostigmata) and the species occurring in Slovakia. Zootaxa 2585: 1-122.

Metz L. J. 1971. Vertical movement of the Acarina under moisture gradients. Pedobiologia 11: 262-268.

Moore J. C., McCann K., Ruiter P. C. 2005. Modeling trophic pathways, nutrient cycling, and dynamic stability in soils. Pedobiologia 49: 499-510.

Moraza M. 2006. Efecto de la degradación de un encinar de Quercus rotundifolia en la comunidad de ácaros cryptostigmados y mesostigmados (Acari: Cryptostigmata, Mesostigamata) [Degradation effects of forest with Quercus rotundifolia on cryptostigmatid and mesostigmatid mite communities (Acari: Cryptostigmata, Mesostigamata)]. Revista Ibérica de Aracnología 13: 171-182 (in Spanish).

Onete M., PAUCĂ-ComĂNescu M. 2008. Heavy metal content assessment in plants from Bucharest. In: Species Monitoring in the central parks of Bucharest (CRĂCIUN I., Ed.), pp. 23-50, Ars Docendi, University Bucharest.

SAdaka N., Ponge J. F. 2003. Soil animal communities in holm oak forests: influence of horizon, altitude and year. Eur. J. Soil Biol. 39: 197-207.

Salmane I. 2000. Investigation of the seasonal dynamics of soil Gamasina mites (Acari: Mesostigmata) in Pinaceum myrtilosum. Latvia. Ekologia 19: 245-252.

Salmane I., Brumelis G. 2010. Species list and habitat preference of mesostigmata mites (Acari, Parasitiformes) in Latvia. Acarologia 50: 373-394.

Selvin S., Vacca A. 2004. Biostatistics. How it works. Pearson Education, UK.

Skorupski M. 2001. Mites (Acari) from the order Gamasida in the Wielkopolski National Park. Fragm. Faun. 44: 129-167.

Skorupski M., Belter W., Kamczyc J., Wierzbicka A. 2008. Soil mites (Acari, Mesostigmata) of the 'Torfowiska Doliny Izery' Reserve in the Sudety Mountains. Soil Organisms 80: 261-270. 
Skorupski M., Butkiewicz G., Wierzbicka A. 2009. The first reaction of soil mite fauna (Acari, Mesostigmata) caused by conversion of Norway spruce stand in the Szklarska Poręba Forest District. J. Forest Sci. 55: 234-243.

Walter D. E., Proctor H. 1999. Mites - Ecology, Evolution and Behaviour. UNSW Press, Everbest Printing Hong-Kong. 